The expedition has also, during the phase now ended, included botanists for the first time, some with a particular interest in the mangrove swamps on Aldabra. All this will no doubt help to clarify the negotiations now under way between the Royal Society, the Smithsonian Institution and various governments on the establishment of a permanent research station on the island.

\section{Studying for War}

BRITAIN is one of the few western countries that does not possess an independent institution for the study of national defence problems. The Royal United Services Institution last week launched an appeal for funds which will enable it to fulfil this role. Because it is autonomous, RUSI should be able to give advice to Government and industry that is independent of political and service pressures. It could also help to educate the public in the complex issues of military policy. Hitherto RUSI has been restricted to providing a library and lecture system for its members, most of whom belong to the armed services, and to publishing a quarterly journal. Under its new director-general, Air Vice-Marshal S. W. B. Menaul, the institution hopes to extend its activities to a systematic study of Britain's defence problems extending beyond the purely military issues to include the industrial, economic and financial bases of defence policy. Defence and overseas policy in the $1970 \mathrm{~s}$, nuclear disarmament, relations between the armed forces and industry, the economic effect of the defence system, the burden of defence expenditure on foreign exchange and the application of management techniques to the services will all come under discussion.

Industries holding military contracts have a substantial interest in such studies, and the institution expects that their representatives as well as academic students of military affairs will participate in its work. Such industries will, it is hoped, be the main source of the funds for which the institution is appealing. The target is an annual income of $£ 70,000$, of which the Government will provide $£ 2$ for every $£ 5$ contributed publicly. This proportion of Government support will guarantee the institution's independence. Thore may be opportunities for collaboration between RUSI and the Institute for Strategic Studies but, with their spheres of interest in British and in international affairs respectively, there is likely to be little duplication of effort.

\section{Science Research Council Members}

THE Science Research Council has four new members. The appointment of Professor Fred Hoyle, Professor J. C. Gunn, Dr E. Eastwood and Professor H. Ford brings the membership of the council to sixteen. Three members of the council have retired at the end of their terms of office; they are Dr A. Caress, Dr S. C. Curran and Professor C. F. Powell.

None of the new members is a newcomer to the SRC; all have held office or been members of the specialist groups which help to determine its policy. Professor Hoyle, for example, is a member of two such committees and chairman of one of them-the Astronomy Grants and Policy Committee. He is director of the Institute of Theoretical Astronomy at the University of Cambridge. Professor Gunn is Cargill Professor of
Natural Philosophy of the University of Glasgow; Dr Eastwood is an industrialist, director of research for the English Electric Group since 1962. Professor Ford is Professor of Applied Mechanies at Imperial College, London, and head of the department of mechanical engineering.

It would be rash to expect these new appointments to have an immediate and significant effect on the policies of the council. Each of the four new members has already had opportunities for making contributions to the policy of the SRC through the advisory committees. Chemists may be disappointed that their lobby on the SRC has not gained in strength. Biologists may be even more disappointed.

\section{Parliament in Britain}

\section{from our Parliamentary Correspondent}

\section{Pension Schemes}

Mr Jeremy Bray, for the Ministry of Technology, gave an assurance that when the astrophysics staff at Culham Laboratory transfers to the Science Research Council there will be no difficulty about pensions. It was the intention, he said, that these people would remain on AEA conditions, and be retained in the AEA pensions scheme. Legislation would be needed for the purpose, but Mr Bray could not say what form it would take. (Oral answer, April 8.)

\section{Seaton Carew Power Station}

A SHORT adjournment debate on the subject of the proposed power station at Seaton Carew in County Durham gave a number of members an opportunity to express displeasure that the Government had not yet announced whether the station will be coal fired or nuclear fired. Mr Robert Woof, the member for Blaydon, quoted remarks attributed to $\mathrm{Mr}$ Peter Williamson, the Central Electricity Generating Board's planning officer. He said that $\mathrm{Mr}$ Williamson had said that the board had no intention of building a coal fired station, and that if it was prevented from building a nuclear station in the north-east, it would build one in the north-west. Mr Woof said that a coal fired station would be cheaper to build, and it was by no means clear that it would not also be cheaper to run, if the costs to the whole community were taken into account. He called for an independent inquiry to establish which form was cheaper. $\mathrm{Mr}$ Emmanuel Shinwell agreed.

Mr Eric Lubbock put in a good word for nuclear stations, and in particular for the high temperature reactor. This would be far cheaper than any nuclear station now contemplated, he said, and urged careful consideration of the bid put in by the Nuclear Power Group and based on a high temperature reactor. The tenders, he said, should be published, so that everybody could make up their own minds.

$\mathrm{Mr}$ Reginald Freeson, Parliamentary Secretary to the Minister of Power, could make no promises. He hoped a decision would be made soon, but doubted that another enquiry into nuclear power costs would serve a useful purpose. The remarks attributed to Mr Williamson would not prejudice the decision, he said, nor the study which was in progress in the Ministry of Power. The study covered a number of issues, including the load forecasts. He promised that when a decision had been taken, the minister would make a full statement about it. 